\title{
Serial Analysis of Gene Expression in the Chicken Otocyst
}

\author{
Saku T. Sinkkonen, ${ }^{1,3}$ Veronika Starlinger, ${ }^{1,4}$ Deepa J. Galaita, ${ }^{1}$ Roman D. Laske, ${ }^{1}$ Samuel \\ Myllykangas, ${ }^{2}$ Kazuo Oshima, ${ }^{1}$ and Stefan Heller ${ }^{1}$ \\ ${ }^{1}$ Departments of Otolaryngology-Head E Neck Surgery and Molecular $\mathcal{E}$ Cellular Physiology, Stanford University School of \\ Medicine, 801 Welch Road, Stanford, CA 94305-5739, USA \\ ${ }^{2}$ Division of Oncology, Stanford University School of Medicine, CCSR 3240, 269 Campus Drive, Stanford, CA 94305, USA
}

Received: 9 February 2011; Accepted: 2 August 2011; Online publication: 19 August 2011

\begin{abstract}
The inner ear arises from multipotent placodal precursors that are gradually committed to the otic fate and further differentiate into all inner ear cell types, with the exception of a few immigrating neural crest-derived cells. The otocyst plays a pivotal role during inner ear development: otic progenitor cells sub-compartmentalize into non-sensory and prosensory domains, giving rise to individual vestibular and auditory organs and their associated ganglia. The genes and pathways underlying this progressive subdivision and differentiation process are not entirely known. The goal of this study was to identify a comprehensive set of genes expressed in the chicken otocyst using the serial analysis of gene expression (SAGE) method. Our analysis revealed several hundred transcriptional regulators, potential signaling proteins, and receptors. We identified a substantial collection of genes that were previously known in the context of inner ear development, but we also found many new candidate genes, such as SOX4, SOX5, SOX7,
\end{abstract}

Saku T. Sinkkonen and Veronika Starlinger equally contributed to this work.

Electronic supplementary material The online version of this article (doi: 10.1007/s10162-011-0286-z) contains supplementary material, which is available to authorized users.

Present address: Saku T. Sinkkonen, Department of Otolaryngology, Helsinki University Central Hospital, POB 220, FIN-00029 HUCH, Helsinki, Finland.

Present address: Veronika Starlinger, Department of Otorhinolaryngology, Medical University of Vienna, Waehringer Guertel 18-20, 1090 Vienna, Austria.

Correspondence to: Stefan Heller - Departments of OtolaryngologyHead \& Neck Surgery and Molecular \& Cellular Physiology · Stanford University School of Medicine - 801 Welch Road, Stanford, CA 943055739, USA. Telephone: +1-650-7248086; fax: +1-650-7258502?; email: hellers@stanford.edu
SOX8, SOX11, and SOX18, which previously were not known to be expressed in the developing inner ear. Despite its limitation of not being all-inclusive, the generated otocyst SAGE library is a practical bioinformatics tool to study otocyst gene expression and to identify candidate genes for developmental studies.

Keywords: gene array, inner ear development, otic vesicle, SAGE, Sox

\section{INTRODUCTION}

The otic vesicle, or otocyst, is one of the earliest morphological manifestations of the vertebrate inner ear. It arises by invagination of the otic placode, which is an ectodermal thickening that develops near the developing hindbrain. This process happens in chicken embryos during the second and third days of embryonic development (E2-E3). In intermediate stages, the otic placode has folded inward to form a pouch that is also called otic pit. The otic pit subsequently pinches off from the surface ectoderm into the underlying mesenchyme, resulting in the formation of the otocyst.

It has been hypothesized that axis formation of the developing inner ear already happens during otocyst formation, where signals from the surrounding tissues result in the regionalization of the developing otic placode, pit, and otocyst (reviewed in Fekete 1996; Fekete and Wu 2002). Despite a complex patterning process that is already manifest at the otocyst stage by regionalized expression of specific markers (for a review, see Streit 2007), the otocyst itself is a remarkable structure because it contains all the necessary progenitor cells to form the major cell types of the inner ear. This autonomy was revealed by grafting otocysts into 
other regions of the developing body (Swanson et al. 1990) as well as by determining that the otic lineage that is specified during otic induction has already reached a largely committed state when the otocyst is formed (Groves and Bronner-Fraser 2000).

Inner ear cell regeneration research has been utilizing the fact that stem cell-derived mammalian otic progenitor cells, defined by the expression of otocyst markers such as PAX2, PAX8, and DLX5, display a certain degree of commitment toward the otic lineage ( $\mathrm{Li}$ et al. 2003a, b; Oshima et al. 2007, 2010). This was demonstrated by showing the potential of otic progenitors to differentiate into different cell types that express makers indicative of neurons, hair cells, and supporting cells. Based on these findings, it has been hypothesized that stem cellderived otic progenitors are similar to otocyst cells (Brigande and Heller 2009; Diensthuber et al. 2009).

Here, we present the results of an unbiased interrogation of gene expression in the chicken otocyst. This analysis was spurred by the lack of comprehensive gene expression information at this important stage of development. We decided to utilize serial analysis of gene expression (SAGE), which is a quantitative method that can be used to identify known as well as new genes (Saha et al. 2002; Velculescu et al. 1995). Of the 39,326 seventeen-base pair sequence tags that we found, we evaluated 16,008 unique sequences that resulted in 4,153 unequivocally identified genes. Although our study lacked the sensitivity of more modern high-throughput deep sequencing methods, we consider the results as an important contribution because they provide a comprehensive summary of genes that are expressed at medium and high levels. Our analysis revealed potential signaling proteins and receptors as well as almost 300 transcriptional regulators that are expressed in the chicken otocyst. Some of these regulators have been previously known to play important roles during inner ear development, but we found additional candidate genes, such as several members of the Sox gene family, which have thus far not been evaluated in the context of the developing inner ear.

\section{METHODS}

Tissue dissection, RNA preparation, and SAGE library preparation

Fertilized eggs (Gallus gallus) of the white leghorn strain (California Golden Eggs, Dinuba, CA) were incubated at $38^{\circ} \mathrm{C}$ for $72 \mathrm{~h}$ on a rocking platform in a humidified egg incubator (Sportsman 1202A, GQF Manufacturing, Savannah, GA). The embryos were removed from the eggs, washed in Hanks' balanced salt solution (HBSS; Invitrogen, Carlsbad, CA), and collected in HBSS. Staging was conducted according to Hamburger and Hamilton's ( $\mathrm{HH}$ ) guidelines (Hamburger and Hamilton 1992), and only HH stage 18-19 embryos with clearly identifiable closed otic vesicles and unpigmented eyes were used. Otic vesicles were microdissected using fine forceps and attention was given to remove as much of the surrounding periotic mesenchyme as possible (Fig. 1A). The vesicles were individually inspected and frozen in bulks of 10-20 in liquid nitrogen and stored at $-80^{\circ} \mathrm{C}$.

Total RNA was isolated using a commercial kit (RNeasy Mini Kit, Qiagen, Hilden, Germany). RNA integrity and quality was confirmed by gel electrophoresis and by visual assessment. Five micrograms total RNA, the combined yield of 200 otocysts, was used for SAGE library synthesis (I-SAGE Long kit, Invitrogen) starting with attaching polyA+ RNA to oligo(dT)-paramagnetic beads, reverse transcription, and second strand synthesis. The resulting cDNA was cleaved with NlaIII, divided into two fractions, and bound to two different adapters containing a type IIS restriction nuclease recognition site. The adapters with adjacent 21-bp cDNA pieces were released from the oligo(dT)-magnetic beads using the type IIS restriction endonuclease $M m e$ I. The two pools of released adapter-linked tags were ligated to 130 -bp
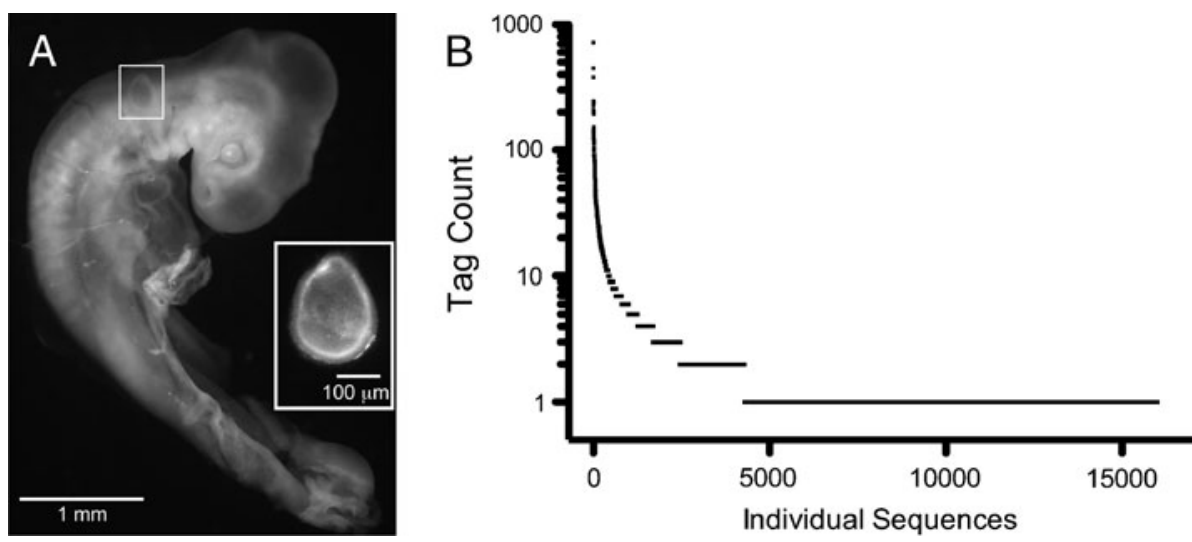

FIG. 1. SAGE library from the chicken otocyst. A HH stage 18-19 chicken embryo. The otocyst is indicated with a white box. Inset, otocyst after dissection. B SAGE tag frequency (tag count) plot for all tags identified. 
ditags and amplified with 27 PCR cycles with specific primers to each adapter. The adapters were then cleaved with NlaIII, 34-bp ditags were purified from the adapters by polyacrylamide gel electrophoresis, and concatenated. Concatemers were fractioned by size, gel-purified, and then cloned into pZErO-1 provided with the kit.

Quality control was conducted in two steps. First, 20 colonies were picked, plasmid DNA was prepared, and the resulting plasmids were digested with NsiI, which resulted in the release of the individual inserts. We obtained 20 distinct restriction patterns with a mean insert length of $671 \mathrm{bp}( \pm 425 \mathrm{bp}(\mathrm{SD}))$. The smallest fragment was $200 \mathrm{bp}$ and the largest was 1,700 bp. In a second step, we sequenced 24 inserts, obtaining 12,025 bp of raw data. These insert lengths slightly exceeded the expected $\approx 25$ SAGE tags per clone predicted by the kit manufacturer. Three thousand eight hundred forty colonies were robotically picked and the plasmid concatemer inserts were directly sequenced (GeneWiz, South Plainfield, NJ).

Modifications from the manufacturer's protocol included that the gel electrophoreses for the 130- and 34-bp ditags were performed on $10 \%$ polyacrylamide gels (Novex TBE Gels, Invitrogen) and that DNA was isolated from polyacrylamide gels with QIAEXII beads (Qiagen). Concatemers were separated on a $2 \%$ agarose gel and purified before subcloning with a column-based gel extraction kit (QIAquick, Qiagen).

\section{Data analysis}

At the highest stringency settings for DNA sequence quality and tag extraction, 39,326 individual 17-bp tags were extracted from the 3,512 sequencing data files using SAGE2000 analysis software (version 4.5, Invitrogen). Only unequivocal sequences were used for library construction, which resulted in a library about three times smaller than predicted by the quality control samples. A potential reason for this shortfall might be that the sequence quality achieved with direct sequencing was lower than the sequencing results obtained with plasmid DNA, which was used for the quality control clones. For computerized mapping, we appended the NlaIII restriction site $\left(5^{\prime}\right.$ CATG-3') to the $5^{\prime}$ end of each tag. The resulting 21-bp tags were mapped using 22,290 G. gallus cDNA sequences available through the Ensembl 52 database (www. ensembl.org/info/data/ftp/), 19,307 G. gallus cDNAs available from the RefSeq database (ftp.ncbi.nih.gov), and 33,383 G. gallus sequences from the Unigene database (www.ncbi.nlm.nih.gov/unigene). Mapping was conducted using MAQ software (Li et al. 2008; maq.sourceforge.net) with all parameters set to default allowing for two mismatches in the sequence alignments. Ingenuity Pathway Analysis (IPA) software was accessed via the Stanford University Bioinformatics Resource (cmgm.stanford.edu).

\section{Reverse transcriptase PCR}

Chicken otocyst RNA was isolated (Absolutely RNA Miniprep Kit, Stratagene/Agilent Technologies, La Jolla, CA) and treated with RNase-free DNase I (Roche Diagnostics, Mannheim, Germany). The RNA concentration was determined by spectrophotometric analysis using a NanoDrop (Thermo Fisher Scientific, Wilmington, DE). Total RNA extracts were then used for reverse transcription (RT) into cDNA (first strand) using SuperScript III Reverse Transcriptase (Invitrogen) and Oligo $(\mathrm{dT})_{18}$ primer (Invitrogen) with $350 \mathrm{ng}$ of total RNA per $20 \mu \mathrm{l}$ reaction. To prevent RNA degradation, $1 \mu$ l RiboLock RNase Inhibitor (Fermentas, Thermo Fisher Scientific, Glen Burnie, MD) was also included in each reaction. Control reactions were done without reverse transcriptase.

Oligonucleotide primer pairs were designed for each gene of interest using NCBI Primer-BLAST (www.ncbi.nlm.nih.gov/tools/primer-blast) with NCBI Reference Sequences as template. For each gene tested, at least two primer pairs covering two nonoverlapping 300- to 700-bp regions were used to confirm mRNA expression. A full list of primers tested can be found in Electronic supplementary materials (ESM) Table 1. PCR was performed using GoTaq Green Master Mix (Promega, Madison, WI) with $2 \mu \mathrm{l}$ cDNA template and $1 \mu \mathrm{l} 400 \mathrm{nM}$ each of forward and reverse gene-specific primers. The following cycling conditions were employed: initial denaturation at $94^{\circ}$ C (3 min); 30 cycles of denaturation at $94^{\circ} \mathrm{C}(30 \mathrm{~s})$, annealing at $55^{\circ} \mathrm{C}(1 \mathrm{~min})$, and elongation at $72^{\circ} \mathrm{C}$ ( $1 \mathrm{~min})$; and a hold at $4^{\circ} \mathrm{C}$. Aliquots of PCR products were electrophoresed in a $2.0 \%$ agarose gel, stained with SYBR Safe (Invitrogen) in 1X TAE buffer at $120 \mathrm{~V}$ for $35 \mathrm{~min}$, and documented using UV transillumination and digital photography (Kodak Gel Logic 200 Imaging System).

\section{In situ hybridization}

The T7 promoter sequence (5'-TAATACGACTCAC TATAGGG- $3^{\prime}$ ) was added to the $5^{\prime}$ end of the forward or reverse primer for the different Sox 2 cDNAs to allow for conversion of the PCR product to sense and antisense cRNA probes for in situ hybridization. Of the PCR product, $500 \mathrm{ng}$ was used to synthesize digoxigenin-labeled antisense probes (DIG RNA Labeling Kit, Roche Diagnostics), which were resuspended in $30 \mu \mathrm{l}$ RNAse-free water. Embryos were dissected at HH stage 18-19 (E3) and HH stage 26-28 (E5), fixed overnight with $4 \%$ paraformaldehyde in phosphate-buffered saline (PBS, $\mathrm{pH}$ 7.4), transferred 
into 30\% sucrose in PBS for $24-36 \mathrm{~h}$, and embedded in O.C.T compound (Tissue-Tek). Sections were cut with a cryomicrotome (CM3050 S, Leica), collected on ultrastick slides (precleaned Gold Seal, Rite-on, Micro Slides), dried at $37^{\circ} \mathrm{C}$ for $45 \mathrm{~min}$, and stored frozen at $-70^{\circ} \mathrm{C}$. For hybridization, the sections were brought to room temperature and rehydrated in $100 \mu \mathrm{l}$ diluted probe $(1: 100)$ in $50 \%$ formamide, $10 \%$ dextran sulfate, $1 \mathrm{mg} / \mathrm{ml}$ yeast RNA, $1 \mathrm{x}$ Denhardt's solution, $185 \mathrm{mM} \mathrm{NaCl}, 5.6 \mathrm{mM} \mathrm{NaH} \mathrm{PO}_{4}, 5 \mathrm{mM}$ $\mathrm{Na}_{2} \mathrm{HPO}_{4}, 5 \mathrm{mM}$ EDTA, and $15 \mathrm{mM}$ Tris at $\mathrm{pH}$ 7.5. After coverslipping and overnight incubation at $65^{\circ} \mathrm{C}$ in a chamber humidified with $50 \%$ formamide in $150 \mathrm{mM}$ $\mathrm{NaCl}, 15 \mathrm{mM}$ trisodium citrate, $\mathrm{pH} 7(1 \times \mathrm{SSC})$, the coverslips were removed in 5x SSC and the slides washed twice for $30 \mathrm{~min}$ each in $50 \%$ formamide and $0.1 \%$ Triton X-100 in 1x SSC at $65^{\circ} \mathrm{C}$. Thereafter, the slides were washed for $15 \mathrm{~min}$ in $0.2 \mathrm{x}$ SSC and for $15 \mathrm{~min}$ in $150 \mathrm{mM} \mathrm{NaCl}$ and $100 \mathrm{mM}$ Tris at $\mathrm{pH} 7.5$ at room temperature. For antibody detection, the sections were blocked for $30 \mathrm{~min}$ in $0.5 \%$ blocking powder (Roche Diagnostics), $10 \%$ heat-inactivated goat serum, $100 \mathrm{mM}$ $\mathrm{NaCl}, 0.1 \%$ Triton $\mathrm{X}-100$, and $100 \mathrm{mM}$ Tris at $\mathrm{pH} 7.5$. The slides were then incubated for $2 \mathrm{~h}$ at room temperature in a blocking solution pre-incubated for $1 \mathrm{~h}$ with alkaline phosphatase-conjugated anti-digoxigenin Fab fragments (1:500, Roche Diagnostics). Unbound Fab fragments were removed by washing twice for $30 \mathrm{~min}$ each in $150 \mathrm{~m} \mathrm{NaCl}$ and $100 \mathrm{mM}$ Tris at $\mathrm{pH}$ 7.5. The sections were first incubated in detection buffer (100 mM NaCl, $50 \mathrm{mM} \mathrm{MgCl}, 100 \mathrm{mM}$ Tris at pH 9.5) for $10 \mathrm{~min}$. For detection, the sections were then covered with $200 \mu \mathrm{l}$ of chromogen solution consisting of $20 \mu \mathrm{l}$ NBT/BCIP stock solution (Roche Diagnostics) and $50 \mu \mathrm{l}$
Levamisol stock solution (20x concentrate, Invitrogen) in $1 \mathrm{ml}$ detection buffer, coverslipped, and incubated overnight at room temperature in a humidified chamber. Coverslips were removed and color reaction was stopped in $1 \mathrm{mM}$ EDTA and $10 \mathrm{mM}$ Tris at $\mathrm{pH}$ 8.1. Slides were embedded in 50\% glycerol in PBS and coverslipped. Analysis and photography was conducted on an Axiovert 25 microscope with an AxioCam MRC camera, using AxioVision software (V 4.6.3.0, Zeiss).

\section{RESULTS}

\section{SAGE library of the chicken otocyst}

Otocysts were dissected from HH stage 18-19 chicken embryos (Fig. 1A), total RNA was extracted, and subjected to a commercial long-SAGE protocol, resulting in a library of concatemerized tags. Individual clones of SAGE concatemers were sequenced, resulting in 39,326 seventeen-base pair tags with tag counts up to 718 for the most abundant tag; 3,292 tags were represented between two and five times, whereas the majority of tags $(11,717)$ were only found once (Fig. 1B). Overall, we identified 16,008 unique sequence tags (ESM Table 2; NCBI Geo DataSet accession no. GSM651351).

Although the chicken genome has been fully sequenced (The Chicken Genome Consortium 2004), the annotation of chicken genes is far from complete, and consequently, gene annotation needed to be conducted by combining several database resources (Fig. 2). We started by mapping all 16,008 tags consisting of the 4-bp NlaIII restriction site and each individual 17-bp SAGE tag using the MAQ software (Li et al. 2008). Three reference databases were used-Ensembl 52, RefSeq,

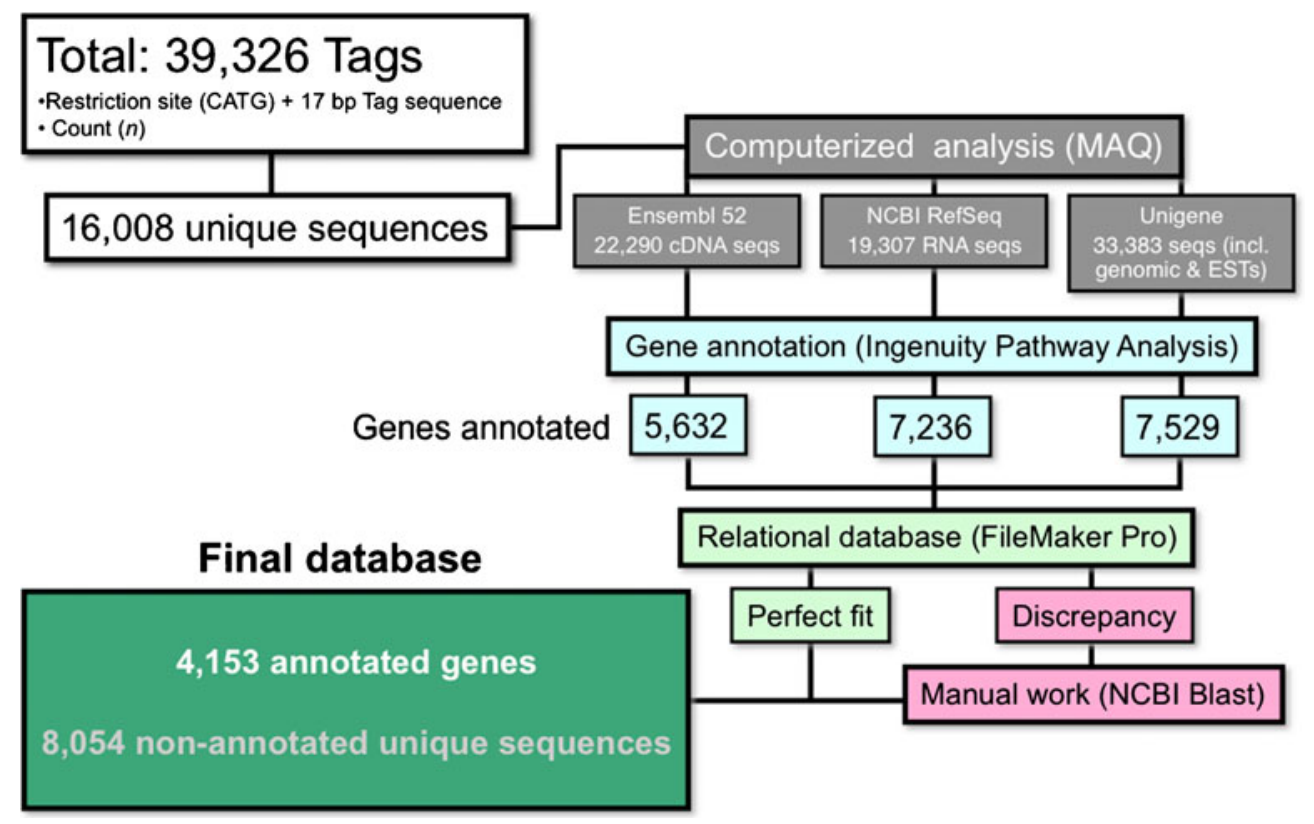

FIG. 2. Flowchart of SAGE tag analysis resulting in a library of 4,153 annotated genes expressed in the chicken otocyst. 
and Unigene-resulting in 7,026, 8,682, and 13,405 matches, respectively. To compare the matches from the three different databases that were composed of assortments of unofficial and official gene names, we imported the results into the IPA software, which revealed official gene symbols as common identifiers. IPA software recognized 5,632, 7,326, and 7,529 gene identifiers from Ensembl, RefSeq, and Unigene database matches, respectively. In a next step, official gene symbols created in IPA were used to directly compare matches of different databases using a relational database. Only when all three different databases suggested a match for a given gene was the gene accepted for further analysis. In case of discrepancies in matches between different databases or in case of missing matches in some of the databases, we performed manual BLAST searches (blast.ncbi.nlm.nih.gov/Blast. cgi) with each tag. If a match was found, the resulting gene was added for further analysis. In 52 cases, a single tag corresponded to two different genes, and in one case, a single tag corresponded to five different genes. These 53 ambiguous tags (ESM Table 3) were removed from further analysis. After this step, the library consisted of 7,912 gene matches with unique tags. However, many genes were represented in the library with two or more different tags, which could be due to alternative poly-adenylation sites, internal priming, or alternative splicing near the $3^{\prime}$ end of the mRNA. These duplicates were combined, resulting in 4,180 genes that were re-imported into IPA for final analysis. At this final step, IPA recognized 4,153 genes, which in the final annotated SAGE library were associated with the aggregate count number of all the tags of every given gene (ESM Table 4).

Gene annotation reveals abundance of transcriptional regulators

Analysis of the relation between tag count and annotated gene number revealed that $50 \%$ of all tags in the otocyst were encoded by only 180 genes, whereas the majority of genes were represented by fewer than 10 tags (Fig. 3A, B). Not unexpectedly, the genes with the highest tag count were housekeeping genes involved in the maintenance of basal cellular functions (Table 1). The IPA database provided unequivocal gene family information for about half of the identified genes. Analysis of all unambiguous gene family annotation identifiers revealed that the majority of otocyst genes encoded unclassified enzymes as well as kinases, phosphatases, and peptidases. The second largest family of genes identified encoded transcriptional regulators, followed by transporters, transmembrane domain-containing receptors, and ion channels (Fig. 3C). Translational regulators, growth factors, cytokines, and other protein families comprised the rest.

Overall, we identified 299 genes that encode transcriptional regulators (ESM Table 5) which can be categorized into transcription factors containing zinccoordinating DNA-binding domains (11\%), helix-loophelix domains (13\%), basic domains (15\%), B-scaffold factors with minor groove contacts $(16 \%)$, and others $(45 \%)$. Fifty-one transcriptional regulators were previously known to be expressed in the developing inner ear. Known examples for each respective category are GATA2 and GATA3 (Lillevali et al. 2007) for zinccoordinating DNA-binding domains, PAX2 and FOXG1 (Herbrand et al. 1998; Li et al. 2004; Pauley et al. 2006) for helix-loop-helix domains, NEUROG1 and NEUROD1 (Liu et al. 2000; Ma et al. 2000) for basic domains, and SOX10 and NOTCH1 (Lewis et al. 1998; Stone and Rubel 1999; Watanabe et al. 2000) for B-scaffold factors with minor groove contacts. Two hundred forty-eight transcriptional regulators were previously unknown in the context of early inner ear development.

\section{Secreted proteins and transmembrane proteins}

Genes that encode growth factors, cytokines, and other secreted proteins are the second group of
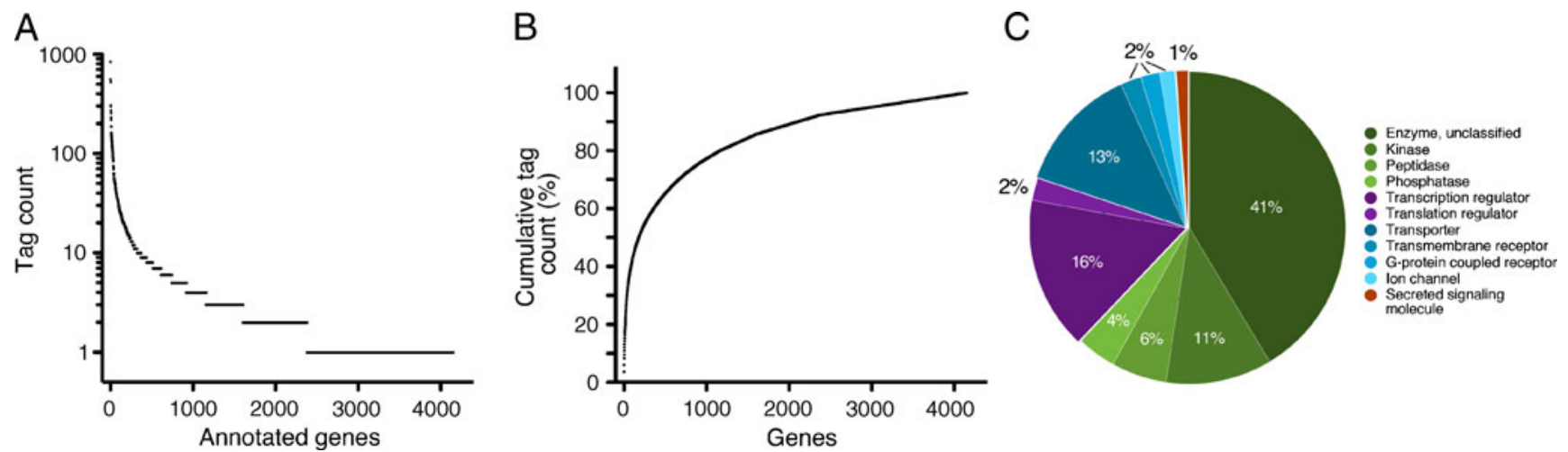

FIG. 3. SAGE library after annotation. A Tag count frequency plot for all 4,153 annotated genes. B Cumulative tag count analysis reveals that 180 of the most abundantly expressed annotated genes represent $50 \%$ of all identified tags. C Family representation of all unambiguously identified annotated genes. 
TABLE 1

Genes with the highest expression based on SAGE tag count

\begin{tabular}{|c|c|c|c|}
\hline Gene symbol & Count & Family & Gene name \\
\hline COX1 & 840 & Enzyme & Cytochrome c oxidase I \\
\hline ARIH1 & 560 & Enzyme & Ariadne homolog, ubiquitin-conjugating enzyme E2 binding protein, 1 \\
\hline COX2 & 526 & Enzyme & Cytochrome c oxidase II \\
\hline COX3 & 307 & Enzyme & Cytochrome c oxidase III \\
\hline ATP6 & 298 & Transporter & ATP synthase 6 , ATPase subunit 6 \\
\hline NPM1 & 273 & Transcription regulator & Nucleophosmin (nucleolar phosphoprotein B23, numatrin) \\
\hline ND4 & 257 & Enzyme & NADH dehydrogenase, subunit 4 (complex I) \\
\hline GAPDH & 254 & Enzyme & Glyceraldehyde-3-phosphate dehydrogenase \\
\hline RPL13 & 230 & Ribosomal structure & Ribosomal protein L13 \\
\hline RPL10A & 218 & Ribosomal structure & Ribosomal protein L10a \\
\hline RPL4 & 187 & Ribosomal structure & Ribosomal protein L4 \\
\hline TUBA4A & 162 & Cytoskeletal structure & Tubulin, $\alpha 4 a$ \\
\hline RPL23 & 161 & Ribosomal structure & Ribosomal protein L23 \\
\hline RPS27A & 156 & Ribosomal structure & Ribosomal protein S27a \\
\hline MDK & 154 & Growth factor & Midkine (neurite growth-promoting factor 2) \\
\hline ND5 & 151 & Enzyme & NADH dehydrogenase, subunit 5 (complex I) \\
\hline RPS3 & 146 & Ribosomal structure & Ribosomal protein S3 \\
\hline EEF1A1 & 142 & Translation regulator & Eukaryotic translation elongation factor $1 \alpha 1$ \\
\hline ATP5B & 139 & Transporter & ATP synthase, $\mathrm{H}+$ transporting, mitochondrial $\mathrm{F} 1$ complex, $\beta$ polypeptide \\
\hline RPS29 & 136 & Ribosomal structure & Ribosomal protein S29 \\
\hline RPS27L & 131 & Ribosomal structure & Ribosomal protein S27-like \\
\hline ACTB & 124 & Cytoskeletal structure & Actin, $\beta$ \\
\hline RPS15 & 120 & Ribosomal structure & Ribosomal protein S15 \\
\hline TUBB2A & 118 & Cytoskeletal structure & Tubulin, $\beta 2 \mathrm{~A}$ \\
\hline RPLP1 & 116 & Ribosomal structure & Ribosomal protein, large, $\mathrm{P} 1$ \\
\hline RPS3A & 112 & Ribosomal structure & Ribosomal protein S3A \\
\hline RPL21 & 107 & Ribosomal structure & Ribosomal protein L21 \\
\hline RPL36 & 102 & Ribosomal structure & Ribosomal protein L36 \\
\hline RPL35 & 96 & Ribosomal structure & Ribosomal protein L35 \\
\hline HNRNPA3 & 94 & Nucleic acid binding & Heterogeneous nuclear ribonucleoprotein A3 \\
\hline
\end{tabular}

developmentally interesting otocyst genes (ESM Table 6). Of the 172 genes that we identified in this group, several were previously known in inner ear development and include BMP7, FGF10, FGF19, FRZB, TGF32, NETRIN1, SLIT1, WNT3, and WNT5A (Abraira et al. 2008; Alsina et al. 2004; Battisti and Fekete 2008; Hollyday et al. 1995; Liu et al. 2008; Oh et al. 1996; Okano et al. 2005; Sanchez-Calderon et al. 2007; Sienknecht and Fekete 2009). Transcripts encoding the secreted signaling protein midkine (MDK) were by far the most abundantly expressed mRNA that we detected. Midkine has been previously reported in the postnatal mouse cochlea, and it has been shown that the protein is involved in regulating the expression of the tectorial membrane component $\beta$-tectorin (Jia et al. 2001; Zou et al. 2006), but early developmental roles in the inner ear have not been reported. Other proteins, such as opticin (OPTC), have previously been shown in the otic vesicle, but their function in inner ear development remains unknown (Frolova et al. 2004). Several genes emerged in our screen as novel candidates for roles in inner ear development, such as olfactomedin-like 2A, 2B, 3 (OLFML2A, OLFML2B, OOLFML3), which belong to a class of proteins implicated in a variety of developmental processes (reviewed by Tomarev and Nakaya 2009), or neudesin $(N E N F)$, which may play roles in neuronal differentiation and development (Kimura et al. 2006). We identified various TGFß antagonists such as twisted gastrulation protein homolog 1 (TWSG1) or follistatinlike 3 (FSTL3). Lastly, we identified various secreted proteins of unknown function during development, but with previous implications in cancer or other cell growth- and death-related processes; examples for these proteins are AGR3, CLU, EGFL7, and HDGF.

Our analysis of transmembrane-spanning proteins revealed high transcript expression levels of many tight junction and cell adhesion proteins such as claudin 1 (CLDN1), CLDN3, and CLDN17; integrins $\alpha 3$ (ITGA3) and $\alpha 6$ (ITGA6); integrins $\beta 1, \beta 2, \beta 3$, and $\beta 5$ (ITGB1, ITGB2, ITGB3, ITGB5); neurexin 1 (NRXN1); as well as cell adhesion molecule 1 (CADM1) and epithelial cell adhesion molecule TACSTD1, among others. One of the most abundant genes identified in this category encodes protein tyrosine kinase 7 (PTK7), a protein implicated in the regulation of planar cell polarity, convergent extension, and Wnt signaling (Lu et al. 2004; Puppo et al. 2011; Yen et al. 2009). Another interesting 
gene in this regard encodes the Ig superfamily protein protogenin (PRTG), which has been shown to play a role in suppressing premature neural differentiation and whose roles in other tissues might similarly be in controlling the timing of transitions between early progenitor state and differentiation (Ito et al. 2011; Wong et al. 2010). Probably the most interesting group of genes that we identified encodes receptors for signaling proteins because they might reveal information about the developmental processes happening in the otocyst. These include genes that encode receptors for ligands that are already known for playing roles in otic development such as FGFR1, FZD1, FZD2, FZD3, FZD4, FZD7, NGFR, and NOTCH1, which have previously been shown to be expressed in the vertebrate otocyst (Adam et al. 1998; Pirvola et al. 2002; Sienknecht and Fekete 2009; Stevens et al. 2003; von Bartheld et al. 1991; Wright and Mansour 2003). BMPR1, BMPR2, LGFR1, SMO1, PTCH1, DISP1, and TGFBR2 are genes that were presumed to be expressed in the otocyst because their ligands, such as BMPs and other TGFß family members, IGF, as well as hedgehog signaling proteins, have been shown to be expressed and active during inner ear development (Bok et al. 2005; Frenz et al. 1991, 1992; Liu et al. 2002; Oh et al. 1996; Riccomagno et al. 2002; Yamashita and Oesterle 1995). Other identified genes include receptors for somatostatin (SSTRI), interleukin 11 (IL11RA), endothelin (EDNRB), and tumor necrosis factors (TNFRSF1A, TNFRSF6B, TNFRSF19) and orphan receptors such as lathrophilin 3 (LPNHN3; Sudhof 2001).

Other potentially interesting transcripts encoded transmembrane proteins involved in cell recognition and adhesion that play roles in axonal guidance and cell migration such as the semaphorins SEMA4B, SEMA5B, SEMA6D, SEMA7A and some components of their receptor complex such as Plexins A1 and B2 (PLXNA1, PLXNB2; Perrot et al. 2002). Additional genes with similar roles include ephrin B1 (EFNB1) and ephrin receptors (EPHA4, EPHA5, EPHB3), netrin G1 and the netrin receptor $U N C 5 B$, the Slit receptors $R O B O 1$ and $R O B O 2$, as well as the Slit-like transmembrane protein SLITRK6. The possible roles of some of these genes in axon guidance and cell migration has been discussed in the context of the inner ear (Fekete and Campero 2007; Webber and Raz 2006), and their expression patterns and potential function are the focus of intensive research (Battisti and Fekete 2008; Katayama et al. 2009; Matilainen et al. 2007).

As initial validation of mRNA expression, we conducted RT-PCR on otic vesicle RNA template with oligonucleotide primer pairs specific for selected genes representing transcriptional regulators, signaling proteins, receptors, and other genes of interest (Fig. 4 and Table 2). Transcripts for all selected genes were detectable, and although the RT-PCR was not conducted in quantitative fashion, we observed a general trend where strong amplification products corresponded to genes with higher SAGE tag counts.

\section{Known and novel Sox genes expressed in the otocyst}

One of the most strongly represented groups of transcription factors in the chicken otocyst SAGE library were the Sox genes. Previous reports show the expression of SOX1, SOX2, SOX3, SOX6, SOX9, SOX10, and SOX21 in the chicken otocyst, or in the otic vesicle of various species including African clawed frog, zebrafish, and mouse (Barrionuevo et al. 2008; Liu et al. 2003; Neves et al. 2007; Uchikawa et al. 1999; Watanabe et al. 2000). Clearly highlighting the limitation of SAGE, showing that about 40,000 tags are far from exhaustive, is the fact that tags for SOX2, $S O X 3$, and SOX6 were not represented in our SAGE library. Nevertheless, we found six Sox genes that previously were not known to be expressed in the developing inner ear, which include SOX4, SOX5, SOX7, SOX8, SOX11, and SOX18.

We verified the expression of the Sox genes by RTPCR (Fig. 4) and by in situ hybridization at the otocyst stage (Fig. 5). SOX8 and SOX11 were abundantly expressed throughout the otocyst and also in the adjacent hindbrain. SOX4 mRNA appeared to be more regionalized with stronger expression in the ventromedial regions of the otocyst, indicative of a potential subsequent expression in the prosensory domains. SOX5 transcripts were weakly detectable throughout the otocyst, with a possible stronger expression in the dorsolateral part of the otocyst. SOX7 and SOX18 mRNA was detectable throughout the otocyst, perhaps with a slightly stronger expression in the ventral portion.

At E5, when the basilar papilla and vestibular compartments of the chicken inner ear are clearly defined and prosensory domains have been formed, only SOX11 appeared to be specifically associated with the prosensory domains of the basilar papilla and vestibular maculae (Fig. 6). SOX7 was no longer detectable, whereas SOX4 and SOX5 transcripts were detectable in the roof of the basilar papilla, presumably in the premordial tegmentum vasculosum. SOX8 expression was strong throughout the inner ear as well as in the adjacent hindbrain (not shown).

\section{DISCUSSION}

The chicken embryo is one of the major animal models used to study inner ear induction and development. In the past decades, many genes have been found that are expressed by cells of the otocyst, and the specific roles of some of these genes have been 


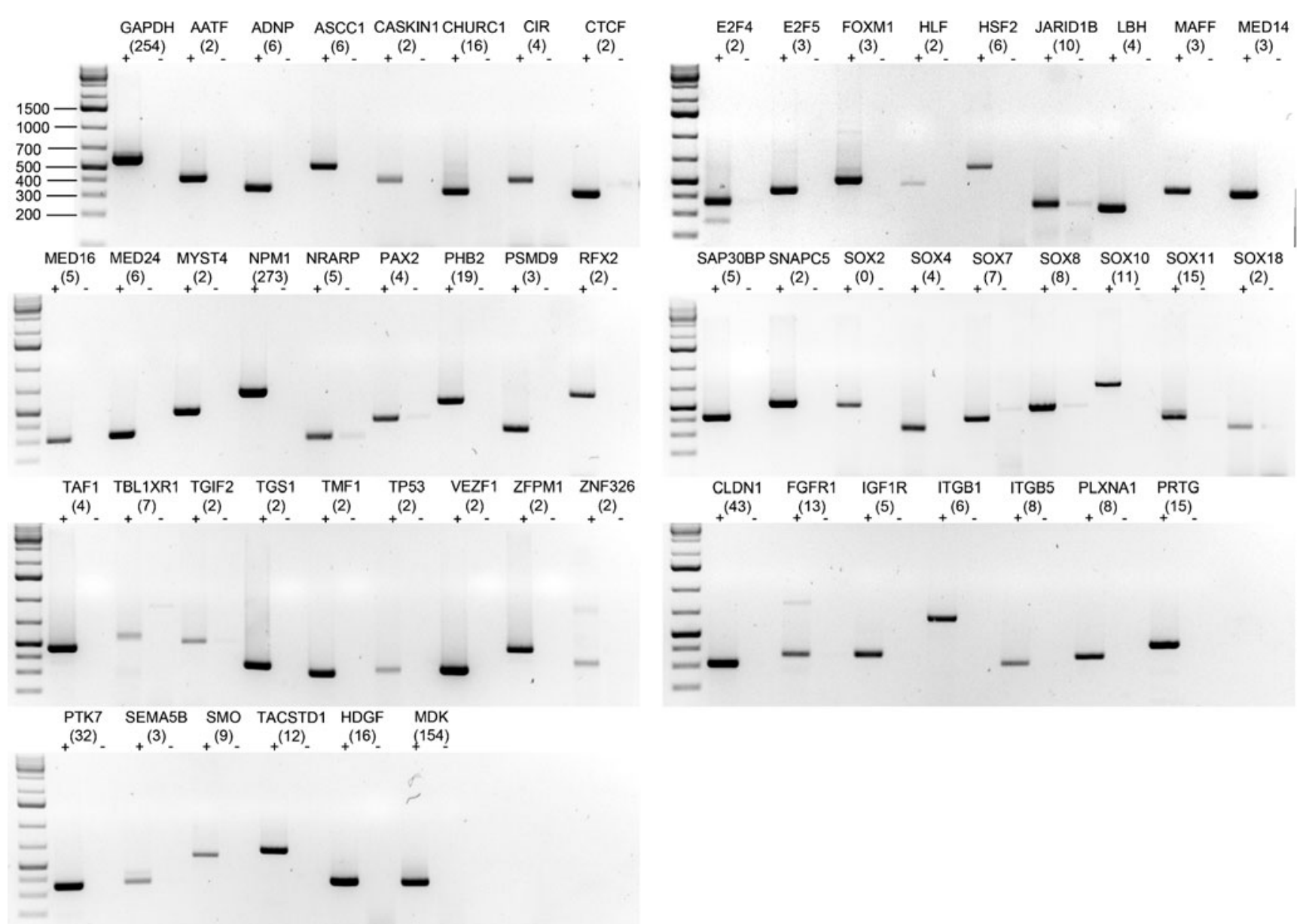

FIG. 4. Shown are agarose gels stained with ethidium bromide to visualize RT-PCR fragments for genes expressed in the chicken otocyst (indicated with " + "). Control reactions without reverse transcription are labeled with " - ". Faint bands in the " - " control lanes are likely the result of residual genomic DNA contamination. The corresponding gene names are listed in Table 2. Predicted PCR product sizes are listed in ESM Table 1. SAGE tag count numbers are indicated in parentheses.

elucidated. Nevertheless, no comprehensive study has been conducted on gene expression in the chicken otocyst. We hypothesized that the existing collection of otocyst markers and genes is just the tip of an iceberg, and we consequently decided to investigate, using a high-throughput method, gene expression in this clearly defined transient structure. Unlike the mouse and human genomes, the chicken genome is comparably poorly annotated, which complicated the analysis strategy. We refrained from using gene arrays whose preselected genes are constrained by these shortcomings. Additionally, at the onset of this study, no comprehensive chicken gene arrays were commercially available and next-generation sequencing techniques, likewise, were not yet developed. We decided to employ SAGE, which is a relatively unbiased method, based on sequencing of short tags that are directly adjacent to a NlaIII restriction site in the $3^{\prime}$ region of any given mRNA (Velculescu et al. 1995). The NlaIII recognition sequence is 4-bp long ( $5^{\prime}-$ CATG-3') and theoretically occurs once in every 256 bp. Using long-SAGE (Saha et al. 2002), which employs 17-mer tags instead of 10-mer tags, which were used in initial SAGE protocols, we were able to utilize a specificity of $4^{21}$. Indeed, we only found 53 ambiguous tags, which either occur more than once in the transcriptome or were associated with more than one gene as a result of annotation ambiguities.

Our analysis is not based on comparative or subtractive studies, and consequently, many genes identified are widely expressed. Nevertheless, the results of our study do not preclude the use of bioinformatic tools to extract subtractive or otherwise user-defined datasets, and the reader is encouraged to use our dataset as needed. A recent very elegant gene array study focusing on FGF-based otic induction in mouse embryos is an example of the powerful specificity that can be achieved by selecting proper tissues for comparison (Urness et al. 2010). In this specific case, wild-type mouse otic placode tissue was compared with tissue from the prospective otic placode of $\mathrm{Fg}^{3-1} ; \mathrm{FgflO}^{--}$mice in which otic development fails to be initiated. This study revealed several transcriptional regulator genes that depend on FGF-based otic induction, including $H m \times 2, H m \times 3$, Foxg1, 
TABLE 2

Index for gene names shown in Figure 4

Gene symbol

Gene name

Tag count

Housekeeping genes

GAPDH

Transcriptional regulators

AATF

ADNP

ASCC1

CASKIN1

CHURC1

CIR

CTCF

E2F4

E2F5

FOXM1

HLF

HSF2

JARID1B

LBH

MAFF

MED14

MED16

MED24

MYST4

NPM1

NRARP

PAX2

PHB2

PSMD9

RFX2

SAP30BP

SNAPC5

SOX2

SOX4

SOX7

SOX8

SOX10

SOX11

SOX18

TAF1

TBL1XR1

TGIF2

TGS1

TMF1

TP53

VEZF1

ZFPM1

ZNF326

Transmembrane proteins
CLDN1
FGFR1
IGF1R
ITGB1
ITGB5
PLXNA1
PRTG
PTK7
SEMA5B

SMO

TACSTD1

Growth factors

HDGF

MDK
Glyceraldehyde-3-phosphate dehydrogenase

Apoptosis antagonizing transcription factor

Activity-dependent neuroprotector homeobox

Activating signal cointegrator 1 complex subunit 1

CASK interacting protein 1

Churchill domain containing 1

CBF1 interacting corepressor

CCCTC-binding factor (zinc finger protein)

E2F transcription factor 4, p107/p130-binding

E2F transcription factor 5, p130-binding

Forkhead box M1

Hepatic leukemia factor

Heat shock transcription factor 2

Jumonji, AT rich interactive domain 1B

Limb bud and heart development homolog (mouse)

$\mathrm{v}$-maf musculoaponeurotic fibrosarcoma oncogene homolog $\mathrm{F}$ (avian)

Mediator complex subunit 14

Mediator complex subunit 16

Mediator complex subunit 24

MYST histone acetyltransferase (monocytic leukemia) 4

Nucleophosmin (nucleolar phosphoprotein B23, numatrin)

$\mathrm{NOTCH}$-regulated ankyrin repeat protein

Paired box 2

Prohibitin 2

Proteasome (prosome, macropain) 26S subunit, non-ATPase, 9

Regulatory factor X, 2 (influences HLA class II expression)

SAP30 binding protein

Small nuclear RNA activating complex, polypeptide 5, 19 kDa

SRY (sex determining region Y)-box 2

SRY (sex determining region Y)-box 4

SRY (sex determining region Y)-box 7

SRY (sex determining region Y)-box 8

SRY (sex determining region Y)-box 10

SRY (sex determining region Y)-box 11

SRY (sex determining region Y)-box 18

TAF1 RNA polymerase II, TATA box binding protein

(TBP)-associated factor, $250 \mathrm{kDa}$

Transducin (beta)-like 1 X-linked receptor 1

TGFB-induced factor homeobox 2

Trimethylguanosine synthase homolog (S. cerevisiae)

TATA element modulatory factor 1

Tumor protein $\mathrm{p} 53$

Vascular endothelial zinc finger 1

Zinc finger protein, multitype 1

Zinc finger protein 326

2

6

6

2

16

4

2

2

3

3

2

6

10

4

3

3

5

Claudin 1

Fibroblast growth factor receptor 1

Insulin-like growth factor 1 receptor

Integrin, beta 1 (fibronectin receptor, beta polypeptide,

antigen CD29 includes MDF2, MSK12)

Integrin, beta 5

Plexin A1

Protogenin homolog (Gallus gallus)

PTK7 protein tyrosine kinase 7

Sema domain, seven thrombospondin repeats (type 1 and type 1-like),

transmembrane domain (TM)

and short cytoplasmic domain, (semaphorin) 5B

Smoothened homolog (Drosophila)

Epithelial cell adhesion molecule 

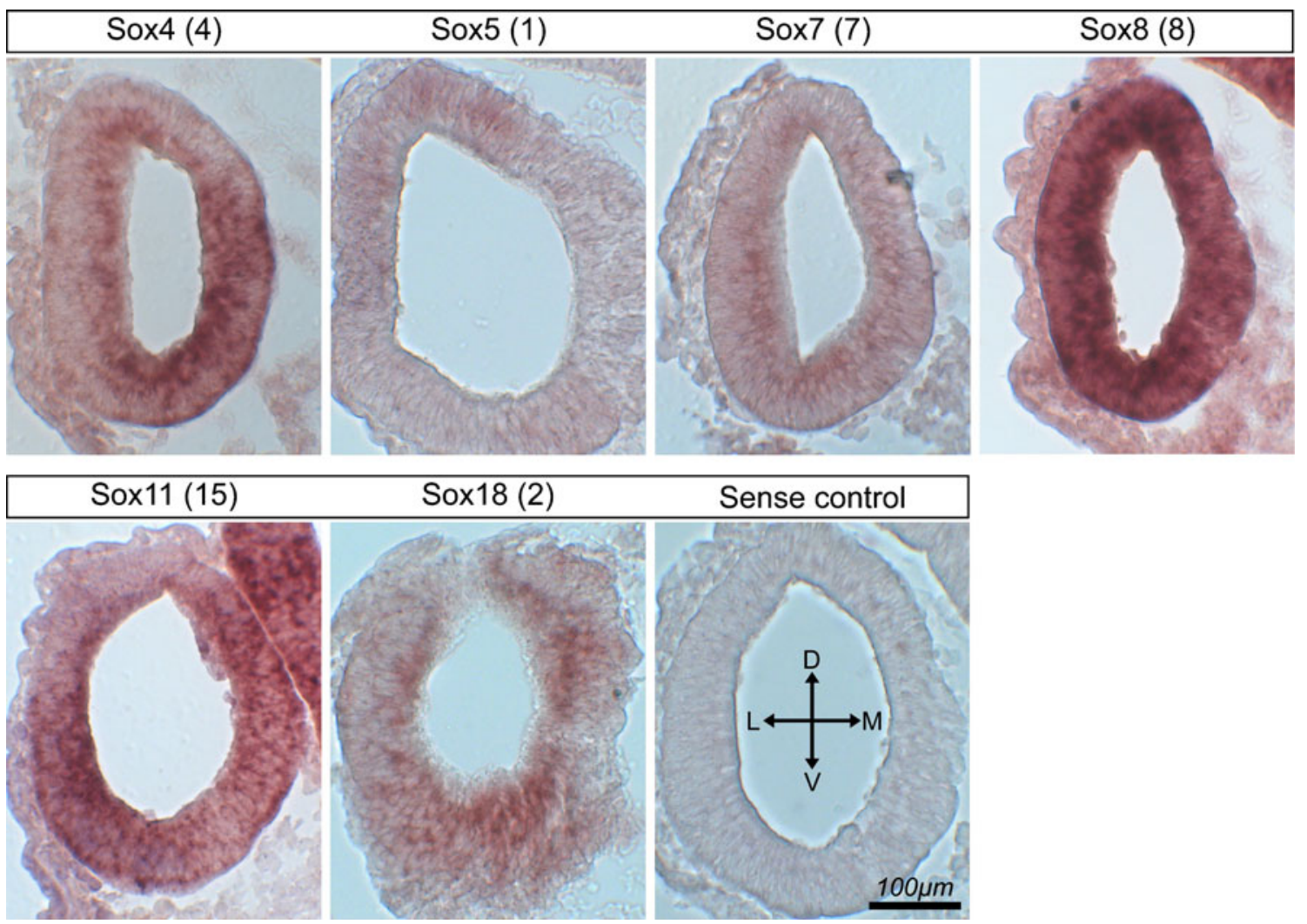

FIG. 5. In situ hybridization analysis of Sox gene expression in sections of the chicken otocyst. Numbers in parentheses indicate the SAGE tag count for each individual gene. Sense controls were negative for all probes used; a representative control is shown.

and Sox9, which we also found in our dataset. Other studies that focused on the identification of otocyst genes used differential display of chicken otocyst RNA against RNA from surrounding tissues (Gong et al.
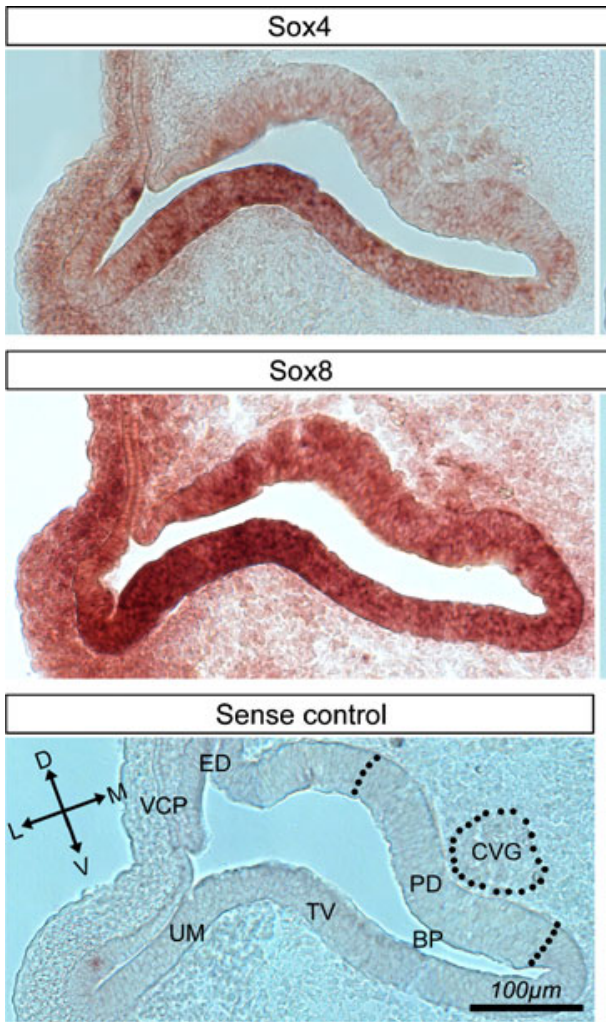

Sox5

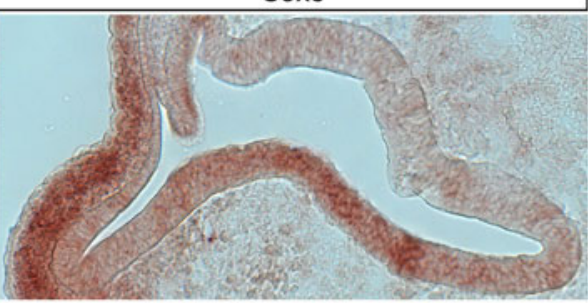

Sox11

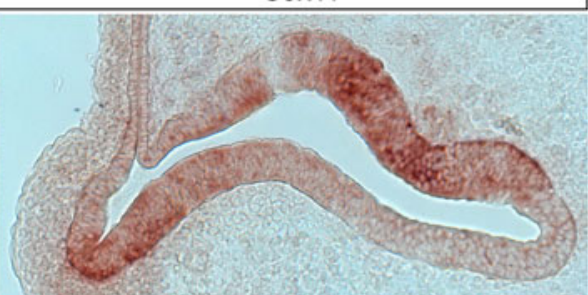

Primordial structures of:

VCP Vertical canal pouch

ED Endolymphatic duct

UM Utricular macula

TV Tegmentum vasculosum

PD Prosensory domain

BP Basilar papilla

CVG Cochlear vestibular ganglion
FIG. 6. In situ hybridization analysis of Sox gene expression in cross-sections of the E5 chicken inner ear. Sense controls were negative for all probes used; a representative control is shown. 
1997) and on cDNA subtraction of mouse otocyst minus liver cDNA (Powles et al. 2004). The differential display study identified only a small number of unknown genes, and the collection of 280 specific transcripts found in the mouse otocyst cannot be directly compared with our data because the dataset was only partially annotated and has not been deposited in a format usable for in silicio comparison, for example via the NCBI Gene Expression Omnibus (GEO) database (http://www. ncbi.nlm.nih.gov/geo/).

An obvious limitation of the SAGE method is the number of tags which results in libraries that are reasonable large, but that are far from exhaustive, particularly when dealing with complex tissues consisting of different cell types. Analysis of our chicken otocyst dataset clearly revealed this limitation. For example, known and easily detectable otocyst genes such as SOX2, PAX8, and FOXI3 (Groves and BronnerFraser 2000; Ohyama and Groves 2004; Uchikawa et al. 1999; Wood and Episkopou 1999) were not represented in our library, and $45 \%$ of all annotated tags were only represented once. The consequence of this limitation is probably a major reason why the SAGE method appears to be a transient technology that is in the process of being replaced with much more comprehensive and massive parallel next-generation sequencing methods capable of generating datasets of tens of millions of tags with a single run. Likewise, microarray and cross-species comparison methods are becoming increasingly more accessible to study gene expression in avian species and have already been successfully used in recent years (Hawkins et al. 2007).

Despite these limitations, we were able to identify a large number of genes that previously were not known in the context of early inner ear development. Particularly transcriptional regulators were well represented in the library, and we were able to validate the expression of SOX4, SOX5, SOX7, SOX8, SOX11, and SOX18, all of which were previously not known to be expressed in the early developing inner ear. Analysis of the interaction networks of these transcription factors revealed some relation to various signaling pathways, including FGF, TGFß/BMP, EGF, and IGF signaling (Fig. 7). Furthermore, we showed for the first time the expression of SoxC group genes (SOX4 and SOX11) as well as SoxF genes (SOX18) in the developing otocyst. We are just beginning to understand the interplay of different signaling pathways and the particular roles of Sox transcription factors in specific developmental processes. Previous studies with mouse Sox genes that are expressed in the otocyst show involvement in placode invagination for Sox9 (Barrionuevo et al. 2008) as well as prosensory specification for Sox2 (Kiernan et al. 2005). The

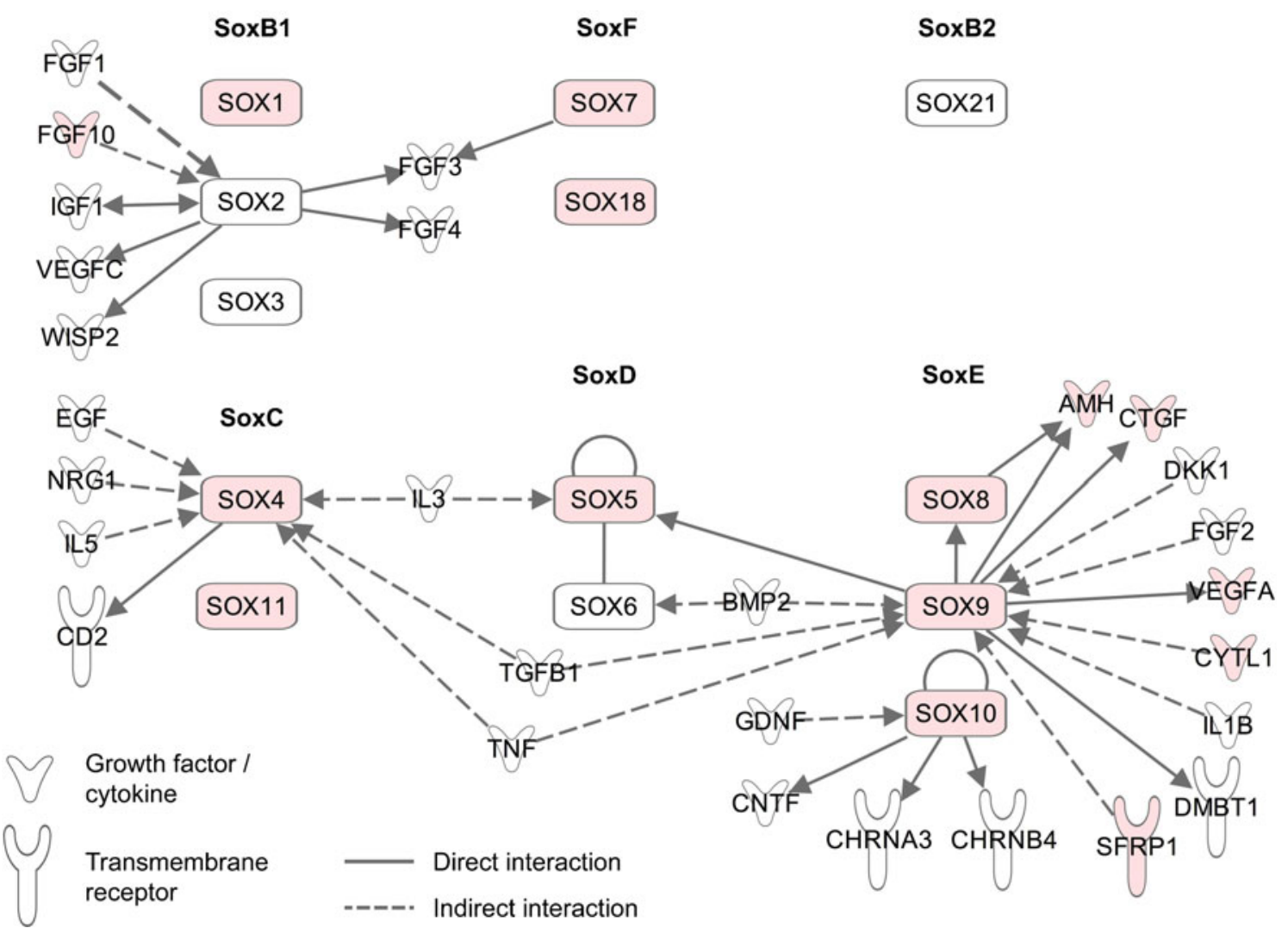

FIG. 7. IPA software analysis of direct and indirect interactions of inner ear Sox genes with growth factors and transmembrane receptors. Genes present in the annotated chicken otocyst SAGE library are labeled in pink. 
overlapping expression of many Sox genes combined with a potential functional redundancy will make it difficult to study individual Sox gene function in the otocyst because single knockouts might lack a phenotype. Phylogeny, neofunctionalization, and redundancies within the Sox gene family have recently been comprehensively reviewed, highlighting the importance of this group of genes in many developmental processes (Guth and Wegner 2008).

Our analysis also revealed many other potentially important genes that have not previously been considered in the context of inner ear development, and some have just recently been investigated. We found a number of secreted proteins that are novel candidates for signaling functions in the developing otocyst. Transmembrane proteins consisted of members of previously known families of proteins that are essentially involved in inner ear development such as receptors for FGFs, BMPs, and WNTs, as well as NOTCH1, among others. Interestingly, we found a relatively large group of proteins belonging to families that have been implicated in axonal guidance and cell migration; some of these proteins have previously been shown to be expressed in the otocyst and other developmental stages of the inner ear (Battisti and Fekete 2008; Matilainen et al. 2007). The expression and function of Slit-like transmembrane protein SLITRK6, for example, has recently been analyzed in mouse inner ear development (Katayama et al. 2009). Slitrk6 is strongly expressed in the prosensory and sensory patches of the auditory and vestibular organs; the innervation density of these organs was reduced or abolished in Slitrk $\sigma^{1-}$ mice.

In summary, we have used the SAGE method to assemble a list of sequence tags that can be associated with gene expression in the chicken otocyst. Although not all-inclusive, this SAGE library is a practical bioinformatics tool to study otocyst gene expression. For user-defined analyses, the library is available in electronic formats that can be directly queried online such as NCBI GEO, or it can be imported into commercial or public domain bioinformatic software packages such as IPA. We used the Sox gene family as an example to highlight the depth as well as the limitations of the library and to demonstrate that the collection of otocyst SAGE tags is a useful tool for molecular and developmental studies of early inner ear development.

\section{ACKNOWLEDGMENTS}

This project was supported by the Sigrid Jusélius Foundation and Instrumentarium Science Foundation (to S.T.S.), a Stanford Dean's Fellowship, and by fellowship D/06/41764 from the German Academic Exchange Service (to V.S.), as well as grants DC006167, DC010042, and P30 DC010363 from the National Institutes of Health (to S.H.).

\section{REFERENCES}

Abraira VE, Del Rio T, Tucker AF, Slonimsky J, Keirnes HL, Goodrich LV (2008) Cross-repressive interactions between Lrig3 and netrin 1 shape the architecture of the inner ear. Development 135:4091-4099

Adam J, Myat A, Le Roux I, Eddison M, Henrique D, Ish-Horowicz D, LEwIs J (1998) Cell fate choices and the expression of Notch, Delta and Serrate homologues in the chick inner ear: parallels with Drosophila sense-organ development. Development 125:4645-4654

Alsina B, Abello G, Ulloa E, Henrique D, Pujades C, Giraldez F (2004) FGF signaling is required for determination of otic neuroblasts in the chick embryo. Dev Biol 267:119-134

Barrionuevo F, Naumann A, Bagheri-Fam S, Speth V, Taketo MM, Scherer G, Neubuser A (2008) Sox9 is required for invagination of the otic placode in mice. Dev Biol 317:213-224

Battisti AC, Fekete DM (2008) Slits and Robos in the developing chicken inner ear. Dev Dyn 237:476-484

Bok J, Bronner-Fraser M, Wu DK (2005) Role of the hindbrain in dorsoventral but not anteroposterior axial specification of the inner ear. Development 132:2115-2124

BRIGANDE JV, Heller S (2009) Quo vadis hair cell regeneration? Nat Neurosci 12:679-685

Diensthuber M, Oshima K, Heller S (2009) Stem/progenitor cells derived from the cochlear sensory epithelium give rise to spheres with distinct morphologies and features. J Assoc Res Otolaryngol 10:173-190

FeKete DM (1996) Cell fate specification in the inner ear. Curr Opin Neurobiol 6:533-541

Fekete DM, Campero AM (2007) Axon guidance in the inner ear. Int J Dev Biol 51:549-556

FEKETE DM, Wu DK (2002) Revisiting cell fate specification in the inner ear. Curr Opin Neurobiol 12:35-42

Frenz DA, VAN de Water TR, Galinovic-Schwartz V (1991) Transforming growth factor beta: does it direct otic capsule formation? Ann Otol Rhinol Laryngol 100:301-307

Frenz DA, Galinovic-Schwartz V, Liu W, Flanders KC, Van de Water TR (1992) Transforming growth factor beta 1 is an epithelialderived signal peptide that influences otic capsule formation. Dev Biol 153:324-336

Frolova EI, Fokina VM, Beebe DC (2004) The expression pattern of opticin during chicken embryogenesis. Gene Expr Patterns 4:335-338

Gong TW, Hegeman AD, Shin JJ, Lindberg KH, Barald KF, Lomax MI (1997) Novel genes expressed in the chick otocyst during development: identification using differential display of RNA. Int J Dev Neurosci 15:585-594

Groves AK, Bronner-Fraser M (2000) Competence, specification and commitment in otic placode induction. Development 127:3489-3499

Guth SI, Wegner M (2008) Having it both ways: Sox protein function between conservation and innovation. Cell Mol Life Sci 65:3000-3018

Hamburger V, Hamilton HL (1992) A series of normal stages in the development of the chick embryo. 1951. Dev Dyn 195:231-272

Hawkins RD, Bashiardes S, Powder KE, Sajan SA, Bhonagiri V, Alvarado DM, Speck J, Warchol ME, Lovett M (2007) Large scale gene expression profiles of regenerating inner ear sensory epithelia. PLoS ONE 2:e525

Herbrand H, Guthrie S, Hadrys T, Hoffmann S, Arnold HH, Rinkwitz-Brandt S, Bober E (1998) Two regulatory genes, $c N k x 5-1$ and $c P a x 2$, show different responses to local signals during otic placode and vesicle formation in the chick embryo. Development 125:645-654

Hollyday M, McMahon JA, McMahon AP (1995) Wnt expression patterns in chick embryo nervous system. Mech Dev 52:9-25 
Ito K, Nakamura H, Watanabe Y (2011) Protogenin mediates cell adhesion for ingression and re-epithelialization of paraxial mesodermal cells. Dev Biol 351:13-24

Jia XQ, Nakashima T, Kadomatsu K, Muramatsu T (2001) Expression of midkine in the cochlea. Hear Res 160:10-14

Katayama K, Zine A, Ota M, Matsumoto Y, Inoue T, Fritzsch B, Aruga J (2009) Disorganized innervation and neuronal loss in the inner ear of Slitrk6-deficient mice. PLoS ONE 4:e7786

Kiernan Ae, Pelling Al, leung KK, Tang AS, Bell DM, Tease C, Lovell-Badge R, Steel KP, Cheah KS (2005) Sox2 is required for sensory organ development in the mammalian inner ear. Nature 434:1031-1035

Kimura I, Konishi M, Mivake A, Fujimoto M, Itoh N (2006) Neudesin, a secreted factor, promotes neural cell proliferation and neuronal differentiation in mouse neural precursor cells. J Neurosci Res 83:1415-1424

Lewis AK, Frantz GD, Carpenter DA, de Sauvage FJ, Gao WQ (1998) Distinct expression patterns of notch family receptors and ligands during development of the mammalian inner ear. Mech Dev 78:159-163

Li H, Liu H, Heller S (2003A) Pluripotent stem cells from the adult mouse inner ear. Nat Med 9:1293-1299

Li H, Roblin G, Liu H, Heller S (2003B) Generation of hair cells by stepwise differentiation of embryonic stem cells. Proc Natl Acad Sci U S A 100:13495-13500

Li H, Liu H, Corrales CE, Mutai H, Heller S (2004) Correlation of Pax-2 expression with cell proliferation in the developing chicken inner ear. J Neurobiol 60:61-70

Li H, Ruan J, Durbin R (2008) Mapping short DNA sequencing reads and calling variants using mapping quality scores. Genome Res 18:1851-1858

Lillevali K, Haugas M, Pituello F, Salminen M (2007) Comparative analysis of Gata3 and Gata2 expression during chicken inner ear development. Dev Dyn 236:306-313

Liu M, Pereira FA, Price SD, Chu MJ, Shope C, Himes D, Еatock RA, Brownell WE, Lysakowski A, Tsai MJ (2000) Essential role of BETA2/NeuroD1 in development of the vestibular and auditory systems. Genes Dev 14:2839-2854

Liu W, Li G, Chien JS, Raft S, Zhang H, Chiang C, Frenz DA (2002) Sonic hedgehog regulates otic capsule chondrogenesis and inner ear development in the mouse embryo. Dev Biol 248:240-250

Liu D, Chu H, Maves L, Yan YL, Morcos Pa, Postlethwait JH, Westerfield M (2003) Fgf3 and Fgf8 dependent and independent transcription factors are required for otic placode specification. Development 130:2213-2224

Liu W, Li L, Li G, Garritano F, Shanske A, Frenz DA (2008) Coordinated molecular control of otic capsule differentiation: functional role of Wnt5a signaling and opposition by sfrp3 activity. Growth Factors 26:343-354

Lu X, Borchers aG, Jolicoeur C, Rayburn H, Baker JC, TessierLAVIGNe M (2004) PTK7/CCK-4 is a NOVEL REgulator of PLANAR CELL POLARITY IN VERTEBRATES. Nature 430:93-98

Ma Q Anderson DJ, Fritzsch B (2000) Neurogenin 1 null mutant ears develop fewer, morphologically normal hair cells in smaller sensory epithelia devoid of innervation. J Assoc Res Otolaryngol 1:129-143

Matilainen T, Haugas M, Kreidberg JA, Salminen M (2007) Analysis of Netrin 1 receptors during inner ear development. Int J Dev Biol 51:409-413

Neves J, Kamaid A, Alsina B, Giraldez F (2007) Differential expression of Sox2 and Sox3 in neuronal and sensory progenitors of the developing inner ear of the chick. J Comp Neurol 503:487-500

Он SH, Johnson R, Wu DK (1996) Differential expression of bone morphogenetic proteins in the developing vestibular and auditory sensory organs. J Neurosci 16:6463-6475
Ohyama T, Groves AK (2004) Expression of mouse Foxi class genes in early craniofacial development. Dev Dyn 231:640 646

Okano J, Takigana T, Seki K, Suzuki S, Shiota K, Ishibashi M (2005) Transforming growth factor beta 2 promotes the formation of the mouse cochleovestibular ganglion in organ culture. Int J Dev Biol 49:23-31

Oshima K, Grimm CM, Corrales CE, Senn P, Martinez Monedero R, Geleoc GS, Edge A, Holt JR, Heller S (2007) Differential distribution of stem cells in the auditory and vestibular organs of the inner ear. J Assoc Res Otolaryngol 8:18-31

Oshima K, Shin K, Diensthuber M, Peng AW, Ricci AJ, Heller S (2010) Mechanosensitive hair cell-like cells from embryonic and induced pluripotent stem cells. Cell 141:704-716

Pauley S, Lai E, Fritzsch B (2006) Foxg1 is required for morphogenesis and histogenesis of the mammalian inner ear. Dev Dyn 235:2470-2482

Perrot V, Vazquez-Prado J, Gutkind JS (2002) Plexin B regulates Rho through the guanine nucleotide exchange factors leukemiaassociated Rho GEF (LARG) and PDZ-RhoGEF. J Biol Chem 277:43115-43120

Pirvola U, Ylikoski J, Trokovic R, Hebert JM, McConnell SK, Partanen J (2002) FGFR1 is required for the development of the auditory sensory epithelium. Neuron 35:671-680

Powles N, Babbs C, Ficker M, Schimmang T, Maconochie M (2004) Identification and analysis of genes from the mouse otic vesicle and their association with developmental subprocesses through in situ hybridization. Dev Biol 268:24-38

Puppo F, Thome V, Lhoumeau AC et al (2011) Protein tyrosine kinase 7 has a conserved role in Wnt/beta-catenin canonical signalling. EMBO Rep 12:43-49

Riccomagno MM, Martinu L, Mulheisen M, Wu DK, Epstein DJ (2002) Specification of the mammalian cochlea is dependent on Sonic hedgehog. Genes Dev 16:2365-2378

Saha S, Sparks AB, Rago C, Akmaev V, Wang CJ, Vogelstein B, Kinzler KW, Velculescu VE (2002) Using the transcriptome to annotate the genome. Nat Biotechnol 20:508-512

Sanchez-Calderon H, Francisco-Morcillo J, Martin-Partido G, Hidalgo-Sanchez M (2007) Fgf19 expression patterns in the developing chick inner ear. Gene Expr Patterns 7:30-38

Sienknecht UJ, FeKete DM (2009) Mapping of Wnt, frizzled, and Wnt inhibitor gene expression domains in the avian otic primordium. J Comp Neurol 517:751-764

Stevens CB, Davies AL, Battista S, Lewis JH, Fekete DM (2003) Forced activation of Wnt signaling alters morphogenesis and sensory organ identity in the chicken inner ear. Dev Biol 261:149-164

Stone JS, Rubel EW (1999) Deltal expression during avian hair cell regeneration. Development 126:961-973

StReit A (2007) The preplacodal region: an ectodermal domain with multipotential progenitors that contribute to sense organs and cranial sensory ganglia. Int J Dev Biol 51:447-461

SudHOF TC (2001) alpha-Latrotoxin and its receptors: neurexins and CIRL/latrophilins. Annu Rev Neurosci 24:933-962

Swanson GJ, Howard M, Lewis J (1990) Epithelial autonomy in the development of the inner ear of a bird embryo. Dev Biol 137:243-257

TOMARev SI, NAKaYA N (2009) Olfactomedin domain-containing proteins: possible mechanisms of action and functions in normal development and pathology. Mol Neurobiol 40:122138

UchiKaWA M, Kamachi Y, KondoH H (1999) Two distinct subgroups of Group B Sox genes for transcriptional activators and repressors: their expression during embryonic organogenesis of the chicken. Mech Dev 84:103-120

Urness LD, Paxton CN, Wang X, Schoenwolf GC, Mansour SL (2010) FGF signaling regulates otic placode induction and 
refinement by controlling both ectodermal target genes and hindbrain Wnt8a. Dev Biol 340:595-604

Velculescu Ve, Zhang L, Vogelstein B, Kinzler KW (1995) Serial analysis of gene expression. Science 270:484-487

von Bartheld CS, Patterson SL, Heuer JG, Wheeler EF, Bothwell M, RubeL EW (1991) Expression of nerve growth factor (NGF) receptors in the developing inner ear of chick and rat. Development 113:455-470

Watanabe K, Takeda K, Katori Y, Ikeda K, Oshima T, Yasumoto K, Saito H, TAKasaka T, Shibahara $S$ (2000) Expression of the Sox10 gene during mouse inner ear development. Brain Res Mol Brain Res 84:141-145

Webber A, Raz Y (2006) Axon guidance cues in auditory development. Anat Rec A Discov Mol Cell Evol Biol 288:390-396

Wong YH, Lu AC, Wang YC, Cheng HC, Chang C, Chen PH, Yu JY, Fann MJ (2010) Protogenin defines a transition stage during embryonic neurogenesis and prevents precocious neuronal differentiation. J Neurosci 30:4428-4439
Wood HB, Episkopou V (1999) Comparative expression of the mouse Sox1, Sox2 and Sox3 genes from pre-gastrulation to early somite stages. Mech Dev 86:197-201

Wright TJ, Mansour SL (2003) Fgf3 and Fgf10 are required for mouse otic placode induction. Development 130:3379-3390

Yamashita H, Oesterle EC (1995) Induction of cell proliferation in mammalian inner-ear sensory epithelia by transforming growth factor alpha and epidermal growth factor. Proc Natl Acad Sci U S A 92:3152-3155

Yen WW, Williams M, Periasamy A, Conaway M, Burdsal C, Keller R, Lu X, SutherLand A (2009) PTK7 is essential for polarized cell motility and convergent extension during mouse gastrulation. Development 136:2039-2048

Zou P, Muramatsu H, Sone M, Hayashi H, Nakashima T, Muramatsu T (2006) Mice doubly deficient in the midkine and pleiotrophin genes exhibit deficits in the expression of beta-tectorin gene and in auditory response. Lab Invest 86:645-653 